\title{
TRANSFUSION TRANSMITTED INFECTIONS (TTIS) AMONG BLOOD DONORS IN THE BLOOD BANK OF A TERTIARY CARE HOSPITAL IN INDIA: A RECORD BASED STUDY
}

\author{
Qureshi Zubair Mohd, ${ }^{1}$ Handoo Shazia, ${ }^{1}$ Sultan Basira, ${ }^{2}$ Reshi Ruby, ${ }^{3}$ Bashir Musharaf ${ }^{4}$ \\ ${ }^{1}$ Department of Transfusion Medicine, GMC\&SMHS hospital, Srinagar, J\&K, India \\ ${ }^{2}$ MBBS student, GMC\&SMHS hospital, Srinagar, J\&K, India \\ ${ }^{3}$ Department of Pathology, GMC\&SMHS hospital, Srinagar, J\&K, India \\ ${ }^{4}$ Department of Physiology, GMC\&SMHS hospital, Srinagar, J\&K, India
}

Primljen/Received 24. 06. 2020. god.

Abstract: Objectives: Transfusion Transmitted Infections (TTIs) are infections caused by potential pathogens which are transmitted to the blood recipients through blood transfusion. This study was primarily carried out to detect sero-positivity of the markers of Hepatitis-B virus (HBV), Hepatitis-C virus (HCV), Human immunodeficiency virus (HIV) and Syphilis in the blood donors at a tertiary care hospital in Srinagar, $\mathrm{J} \& \mathrm{~K}$, India over a of 4 years.

Material and Methods: Blood donations over 4 years from Jan.2015 to Dec. 2018 were reviewed retrospectively from the records of blood bank for seropositivity for HBV, HCV, HIV and Syphilis.

Results: A total of 31733 blood units were collected out of which 24494 (77.19\%) were replacement and 7239 (22.81\%) were voluntary. The seroprevalence of HBV, HCV, HIV and Syphilis was $0.22 \%$ (72), 0.16\% (52), $0.009 \%$ (3) and $0.01 \%$ (5) respectively. A decreasing trend of all the major TTIs was observed over these years. Prevalence of all the four TTIs was observed highest in replacement donors as compared to voluntary donors.

Conclusion: Seroprevalence of all the TTIs was low as compared to the studies from rest of the country. Extensive donor selection and screening procedures will help in improving blood safety more. Efforts should be made to maximise voluntary donations and minimise replacement donations.

Keywords: Seroprevalence, Hepatitis B virus, Hepatitis $\mathrm{C}$ virus, HIV, Syphlis, Blood donor.

\section{INTRODUCTION}

Transfusion Transmitted Infection (TTI) is usually attributed to a pathogen such as a virus or parasite
Prihvaćen/Accepted 15. 09. 2020. god.

which is transmitted from donated blood to the recipient through a blood transfusion (1). There are also other modes of transmission of these infections, such as use of parenteral rugs, unsafe sexual practices, and from mother to child, but blood transfusion remains the main contributor (2). Literature suggests that TTIs are a serious threat to safe transfusion practices. For monitoring the safety of blood donation and to evaluate the efficacy of currently employed screening tests, correct estimates of risk of TTIs are essential (3). Although advancement in technology has led to the development of accurate methods to detect different markers of TTIs, the problems like false negative results, genetic variability in pathogen strains, window period of the disease, prevalence of asymptomatic carriers and technical errors continue to remain (4). Only continuous improvement and implementation of donor selection by detailed history taking and physical examination of the blood donors, screening of donors for high-risk behaviour, development of screening techniques which are sensitive, and different procedures that can eliminate or reduce the risk of acquiring TTIs (5). Unlike in India which heavily relies on replacement of blood donations, the developed countries have made tremendous advances for screening of TTIs (6).

Concealing of medical history poses a heightened threat to blood safety which can be minimised by proper recruitment strategy, voluntary donations, donor education and motivation (3). It has been seen that most of the voluntary donors in India belong to a higher socioeconomic class who are in a better position to understand the implications of questions being asked to the donors. On the other hand, replacement donors are compelled to donate in a short period of time (7). 
Mandatory screening tests for TTIs such as Human Immunodeficiency Virus (HIV), Hepatitis B Virus (HBV), Hepatitis C Virus (HCV) and Syphilis are done in most of the transfusion centres (3). As per a preliminary report by NACO (National AIDS Control Organization) in the year 2016, the prevalence of $\mathrm{HBV}, \mathrm{HCV}$, HIV and Syphilis among blood donors in India for the year 2015 was reported to be $0.94 \%, 0.32 \%, 0.13 \%$ and $0.18 \%$ respectively and the prevalence in Jammu and Kashmir was reported to be $0.32 \%, 0.26 \%, 0.04 \%$ and $0.22 \%$ respectively (8). Detection of TTIs in blood donors not only reduce risk of transmission through infected blood, but also gives an idea about the prevalence of these infections in the general population. This study was primarily carried out to detect seropositivity of the markers of HBV, HCV, HIV and Syphilis in the blood donors at GMC \& SMHS tertiary care hospital, Srinagar, J\&K, India over the period of 4 years. This study was aimed to access the prevalence of TTIs among blood donors at GMC \&SMHS hospital and to estimate the proportions of Voluntary and Replacement donations.

\section{MATERIAL AND METHODS}

This record based cross-sectional study was conducted after getting permission from Institutional Ethical Committee. The study period was from January 2015 to December 2018. Data of blood donors who donated blood from January 2015 to December 2018 was collected from the blood bank of GMC \& SMHS tertiary care hospital, Srinagar J\&K, India. Blood donations over 4 years (Jan 2015 to Dec 2018) were revived retrospectively from the records of blood bank. The data consisted of total blood units collected, number of voluntary and replacement donations and the number of seropositive cases for HBV, HCV, HIV and Syphilis. Enzyme linked immunosorbent assay (ELISA, Trivitron's healthcare, India) test kits such as HBsAg ELISA kit, HCV ELISA kit and HIV-Ag-AbElisa kit were used respectively for the detection of $\mathrm{HBsAg}, \mathrm{HCV}$ and HIV. Rapid test Kits (Immuno Quick Syphilis Ab, Immunoscience Pvt. Limited, Pune, India) were used for detection of Syphilis. Data was analyzed with the help of IBM SPSS version 20, USA (Statistical Package for the Service Solutions).

\section{RESULTS}

A total of 31733 blood units were collected over a period of 4 years (January 2015 to December 2018). Of total donations, 24494 (77.19\%) were replacement and $7239(22.81 \%)$ were voluntary (Figure 1). Yearly trend in replacement and voluntary blood donations is shown in Table 1. The total number of blood donations in the blood bank showed progressive increase from 6800 in 2015 to 9419 in 2018 but there was a progressive decrease in number of voluntary donations over a period of 4 years. Out of 31733 donations, 30974 $(97.60 \%)$ were males and $759(2.40 \%)$ were females as

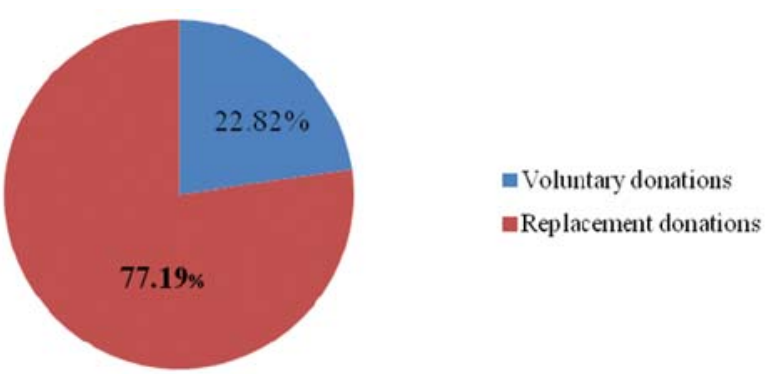

Total blood donations and their distribution.

Figure 1. Shows that around 3/4th of total blood donations were Replacement donations

Table 1. Shows that the total number of blood donations showed progressive increase from 2015 to 2018

\begin{tabular}{|c|c|c|c|}
\hline Year & Replacement donation (\%) & Voluntary donation (\%) & Total donation (\%) \\
\hline 2015 & $4751(69.87)$ & $2049(30.13)$ & $6800(21.43)$ \\
\hline 2016 & $5467(75.93)$ & $1733(24.07)$ & $7200(22.69)$ \\
\hline 2017 & $6430(77.34)$ & $1884(22.66)$ & $8314(26.19)$ \\
\hline 2018 & $7846(83.30)$ & $1573(16.70)$ & $9419(29.69)$ \\
\hline Total & $24,494(77.19)$ & $7239(22.81)$ & $31,733(100)$ \\
\hline
\end{tabular}

Yearly distribution of voluntary and replacement blood donation.

Table 2. Shows percentage of male and female donors

\begin{tabular}{|c|c|c|}
\hline GENDER & Total no of donations & Percentage \\
\hline Male & 30974 & $97.60 \%$ \\
\hline Female & 759 & $2.40 \%$ \\
\hline Total & 31733 & $100 \%$ \\
\hline
\end{tabular}


Table 3. Prevalence of HBsAg, HCV, HIV and Syphilis in blood donors

\begin{tabular}{|c|c|c|c|c|c|}
\hline Year & Total donors & HBsAg positive & HCV positive & HIV positive & VDRL positive \\
\hline 2015 & 6800 & $27(0.39 \%)$ & $16(0.23 \%)$ & $2(0.02 \%)$ & $1(0.01 \%)$ \\
\hline 2016 & 7200 & $16(0.22 \%)$ & $18(0.25 \%)$ & $0(0.00 \%)$ & $1(0.01 \%)$ \\
\hline 2017 & 8314 & $12(0.14 \%)$ & $10(0.12 \%)$ & $0(0.00 \%)$ & $0(0.00 \%)$ \\
\hline 2018 & 9419 & $17(0.18 \%)$ & $8(0.08 \%)$ & $1(0.01 \%)$ & $3(0.03 \%)$ \\
\hline Total & 31,733 & $72(0.22 \%)$ & $52(0.16 \%)$ & $3(0.009 \%)$ & $5(0.01 \%)$ \\
\hline
\end{tabular}

HbsAg; Hepatitis B surface antigen, HCV; Hepatitis C virus, HIV; Human immunodeficiency virus, VDRL; Veneral Disease Research Laboratory.

shown in Table 2 and Figure 2. On screening of 31733 blood donors, 72 donors $(0.22 \%)$ were seropositive for HBsAg, 52 donors $(0.16 \%)$ were seropositive for $\mathrm{HCV}$, 3 donors $(0.009 \%)$ were seropositive for HIV and 5 donors were seropositive for VDRL. The prevalence of HBsAg was observed to range from $0.39 \%$ in 2015 to $0.18 \%$ in 2019 . HCV prevalence $0.23 \%$ in 2015 to $0.08 \%$ in 2018 . HIV prevalence was observed to range from $0.02 \%$ in 2015 to $0.01 \%$ in 2018 . Thus, for all three major TTIs, there was decreasing trend in the prevalence over these 4 years of study as shown in Table 3. This study also evaluated seroprevalence among repla-

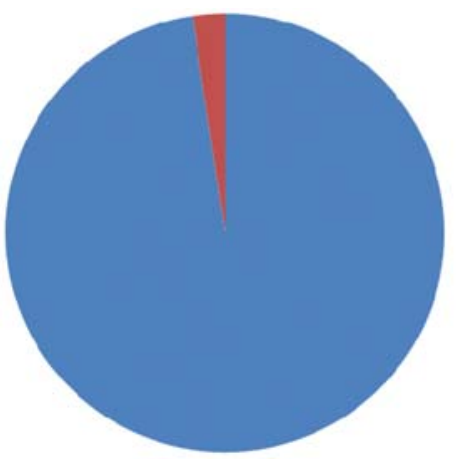

waleblood donors a Female blood donors

Maximum blood donations (97.60\%) were males.

Figure 2. Shows distribution of blood donors

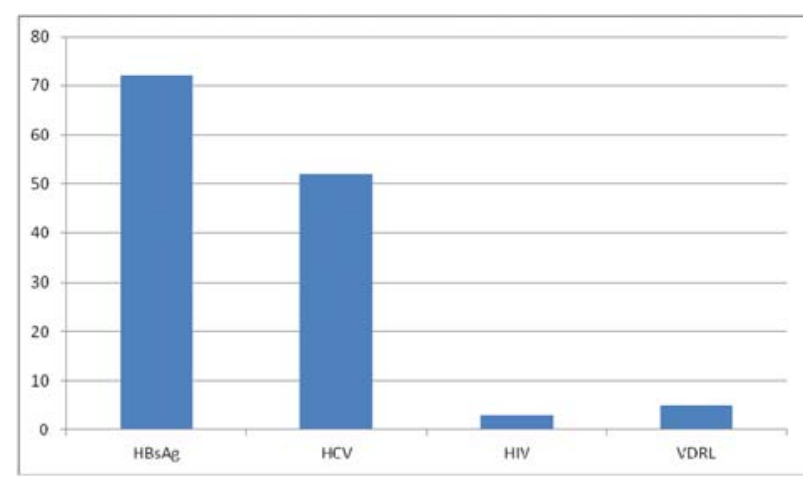

HBsAg; Hepatitis B surface antigen, HCV; Hepatitis $\mathrm{C}$ virus, HIV; Human immunodeficiency virus, VDRL; Veneral Disease Research Laboratory.

Figure 3. Shows HBV as most prevalent infection followed by HCV infection

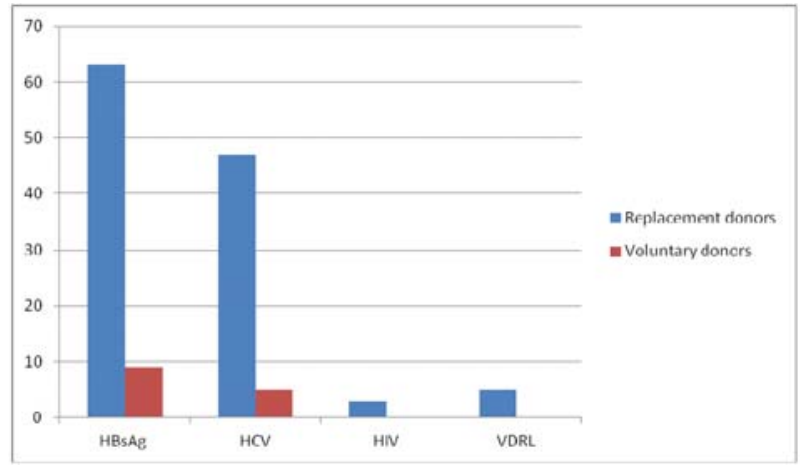

HBsAg; Hepatitis B surface antigen, HCV; Hepatitis $\mathrm{C}$ virus, HIV; Human immunodeficiency virus, VDRL; Veneral Disease Research Laboratory.

Figure 4. Comparison of seroprevalence of TTIs between Replacement and Voluntary donors

cement and voluntary donors and it was observed that prevalence of all the four TTIs was highest in replacement donors as shown in Figure 3. In this study the comparison of seroprevalence of TTIs was made between voluntary and replacement donors as shown in Figure 4. It was observed that replacement donors had a significantly higher prevalence of TTIs.

\section{DISCUSSION}

Blood donations save many lives and has a vital role to play in the supportive care of medical as well as surgical patients but the unsafe transfusion of blood from infected donors to recipients puts millions of lives at risk (9). Unsafe practise of blood transfusion carries a significant risk of transmission of blood borne infections (10). Thus screening of every blood donation is important. Ideally, the standard sample for any seroprevalence study should be taken from general population but this is not always feasible. Therefore, detection of seroprevalence among healthy blood donors serves as a proxy for general population. It is a known fact that young adults are the main blood donors which means that seroprevalence of TTIs among children and elderly cannot be detected by this method (6). 
In this study, an attempt was made to detect seroprevalence of HBV, HCV, HIV and Syphilis among blood donors and to detect the proportion of blood donations in terms of replacement and voluntary donation over the period of 4 years. It was observed that total number of blood donations in the blood bank showed a progressive increase during these 4 years. It was also observed that the seroprevalence of HBV and $\mathrm{HCV}$ infection decreased over these years. This study also highlighted the importance of voluntary donations in the field of transfusion medicine as there is a huge difference in infection rates between replacement and voluntary donors.

In this study low seroprevalence of all the TTIs was observed compared to the rest of the country which is also depicted in NACO 2015 report (8). Low seroprevalence of viral markers (HBV and HCV) as compared to other parts of the country was also observed by Qureshi MZ et al (11) who conducted a 10 year study at a tertiary care hospital. In this study, the seroprevalence of HBV among blood donors was $0.22 \%$ over a period of 4 years. This study is in accordance with the WHO classification (12), which reported Srinagar, J\&K, India as a low prevalence zone $(<2 \%)$ for HBV. In this study among all TTIs, the seroprevalence of HBV was highest in comparison to other infections. Highest seroprevalence of HBV in comparison to other TTIs was also observed by Handoo S et al (13). In this study HCV seroprevalence among blood donors was found to be $0.16 \%$. Mitrovic et al (14) observed HCV seroprevalence of $0.19 \%$ in their study.

In this 4 study, only 3 cases $(0.009 \%)$ of HIV were detected. This may be due to awareness and medical advancement that HIV positive patients are able to come forward and seek medical intervention or it may be because people of high risk behaviour are aware to a certain extent about how to prevent HIV infection and mandatory availability of triple serology tests to be done by patients before any surgical procedure .Moreover, establishment of multiple numbers of Integrated Counselling and Testing Centres (ICTC) for HIV awareness and Opium Substitution Centres (OST) for preventing spread of infection among drug abusers have also limited the cases of HIV in Srinagar, J\&K, India. A study conducted by Mahmood et al (15) observed 0\% seroprevalence of HIV at their blood transfusion centre.In this study, seroprevalence of VDRL was $0.01 \%$; similar results were observed by Chandra $\mathrm{T}$ et al (16). The detection of VDRL is mainly based on sensitivity kits available.
Promotion of voluntary donations would help in reducing the risk of TTIs as recommended by WHO Regional Office for South-East Asia, New Delhi (17). In this study, $22.81 \%$ of the total donations were voluntary and it was observed that seroprevalence of all the four TTIs was highest among replacement donors. Nanu A et al (18) also observed that all the three TTIs viz. HBV, HIV and Syphilis were significantly less frequent in voluntary donors. Similarly, Chandra T et al (16) observed in their 5 year study that prevalence of TTIs was more in replacement in comparison to voluntary donors. Therefore, we recommend that a heavy emphasis should be given to maximize voluntary blood donations so as to minimize the risk of TTIs. In our study decreasing trend in voluntary donations over the period of 4 years is of concern. This calls for awareness programs to be held for general public to promote voluntary blood donations, frequent organization of blood donation camps, better donor recruitment and retention strategies and reducing the replacement donations to minimum.

\section{CONCLUSION}

TTIs have a profound impact on the development of a nation. Methods to ensure a safe blood supply should be encouraged and emphasised. All the blood donors should be selected and screening after taking a thorough history. Thus it is important to give feedback to the blood banks regarding the prevalence of TTIs. Extensive efforts should be made to maximise the practise of voluntary donations and minimise replacement donations.
Abbreviations
TTIs - Transfusion Transmitted Infections
HBV - Hepatitis-B virus
HCV - Hepatitis-C virus
HIV - Human immunodeficiency virus

Conflict of Interests: The authors declare that there are no conflicts of interest related to this article.

Funding: None

\section{Licensing}

This work is licensed under a Creative Commons Attribution 4.0 International (CC BY 4.0) License. 


\title{
Sažetak
}

\section{TRANSFUZIJOM PRENOSIVE INFEKCIJE (TTIS) MEĐU DONORIMA KRVI BANKE KRVI TERCIJARNE ZDRAVSTVENE USTANOVE U INDIJI: STUDIJA ZASNOVANA NA PODACIMA}

\author{
Qureshi Zubair Mohd, ${ }^{1}$ Handoo Shazia, ${ }^{1}$ Sultan Basira, ${ }^{2}$ Reshi Ruby, ${ }^{3}$ Bashir Musharaf ${ }^{4}$ \\ ${ }^{1}$ Department of Transfusion Medicine, GMC\&SMHS hospital, Srinagar, J\&K, India \\ ${ }^{2}$ MBBS student,GMC\&SMHS hospital, Srinagar, J\&K, India \\ ${ }^{3}$ Department of Pathology, GMC\&SMHS hospital, Srinagar, J\&K, India \\ ${ }^{4}$ Department of Physiology, GMC\&SMHS hospital, Srinagar, J\&K, India
}

Uvod: Transfuzijom prenosive infekcije (TTIs) su infekcije uzrokovane potencijalnim patogenima koji su preneti primaocima preko transfuzije krvi. Ova studija je prvenstveno sprovedena radi detektovanja seropozitivnosti markera za Hepatitis-B virus (HBV), Hepatitis-C virus (HCV), Virus humane imunodeficijencije (HIV) i Sifilis u krvi donora, u tercijarnoj zdravstvenoj ustanovi u Srinagaru, J\&K, Indija, tokom 4 godine.

Materijeal i Metode: Donacija krvi tokom 4 godine, od januara 2015. do decembra 2018., je retrospektivno pregledana iz podataka banke krvi koji su se odnosili na seropozitivnost za HBV, HCV, HIV and Sifilis.

\section{REFERENCES}

1. Dean CL, Wade J, Roback JD.Transfusion-Transmitted Infections: an update on product screening, diagnostic techniques, and the path ahead. J Clin Microbiol.2018; 56(7): e00352-18.

2. Ray G.Current scenario of hepatitis B and its treatment in India. J Clin Transl Hepatol. 2017; 5(3): 277-96.

3. Patel P, Borkowf CB, Brooks JT, Lasry A, Lansky A, Mermin J.Estimating per-act HIV transmission risk: a systematic review. AIDS.2014; 28(10): 1509-19.

4. Kondareddy S.Seroprevalence of co-infections among blood donors at the blood bank of a tertiary care hospital, in Southern India. J Evid Based Med Healthc. 2018; 5(38): 2723-6.

5. Bihl F, Castelli D, Marincola F,Dodd RY, Brandr C. Transfusion-transmitted infections. J Transl Med.2007; 5:25. https://doi.org/10.1186/1479-5876-5-25.

6. Towards $100 \%$ Voluntary Blood Donation: A Global Framework for Action. Geneva: World Health Organization; 2010. 2, Voluntary blood donation: foundation of a safe and sufficient blood supply. Available from: https://www.ncbi.nlm. nih.gov/books/NBK305666/

7. Shanti B, Meena AK, Rupam B, Ramasastry G, Sandip VS. Evaluation of therapeutic plasma exchange in neuroimmunological disorders: A study of 15 cases in Nizam's Institute of Medical Sciences, Hyderabad. Asian Journal of Transfusion Science. 2010; 4(1): 43-69.
Rezultati: Ukupno 31733 jedinica krvi je prikupljeno, od kojih je 24494 (77,19\%) bilo zamena, a 7239 (22,81\%) od dobrovoljnih davaoca. Seroprevalenca HBV, HCV, HIV i sifilisa bila je .22\% (72), $0.16 \%$ (52), $0.009 \%$ (3) and $0.01 \%$ (5). Trend opadanja svih glavnih TTIs je primećen tokom poslednjih godina. Prevalenca sve četiri TTIs je najveća u jedinicama krvi iz zamene u poređenju sa dobrovoljnim donorima.

Zaključak: Seroprevalenca svih TTIs je bila niža u odnosu na studije iz ostalih delova sveta. Ekstenzivna selekcija donora i skrining procedure će pomoći u poboljšanju bezbednosti transfuzije. Treba uložiti do-

8. National AIDS Control Organization (NACO) and National Blood Transfusion Council(NBTC), Ministry of Health and Family Welfare, Government of India. www.naco.gov.in

9. Kotwal U, Doda V, Arora S, Bhardwaj S. Blood donor notification and counselling: Our experience from a tertiary care hospital in India. Asian Journal of Transfusion Science. 2015; 9(1): 18-22.

10. Scott SR, Wu Z.Risks and challenges of HIV infection transmitted via blood transfusion. Biosafety and Health. 2019; 1(3): 124-8.

11. Qureshi MZ, Bashir H, Maroof P, Jeelani S, Bhat N, Akhter F. Seropositivity of Hepatitis B virus and Hepatitis C virus among blood donors at a tertiary care hospital in Kashmir: a ten year study. Int J Cur Res Rev. 2016; 8(19): 17-20.

12. World Health Organization, Representative India. Introducing hepatitis $\mathrm{B}$ under universal immunization program frequently asked questions about hepatitis B disease and vaccine. Available at: http://www.whoindia.org/CHS/HepB/FAQ.htm.

13. Handoo S, Ryhan R, Reshi R, Sayeed SI. Seroprevalence of different transfusion transmissible infections among blood donors in a tertiary care hospital of Kashmir: a hospital based sStudy. Int J Med Res Prof. 2018; 4(2): 270-2.

14. Mitrovic N, Delic D, Markovic-Denic L, Jovicic M, Popovic N, Bojovic K et al. Seroprevalence and risk factors for hepatitis $\mathrm{C}$ virus infection among blood donors in Serbia: A multicentre study. Dig Liver Dis. 2015; 47(7): 572-6. 
15. Mahmood MA, Khawar S, Anjum AH, Ahmad SM, Rafiq S, Nazir I et al. Prevalence of Hepatitis B, C and HIV infection in blood donors of Multan Region. Annals of King Edward Medical Univ. 2004; 10(4): 459-61.

16. Chandra T, Rizvi SNF, Agarwal D. Decreasing prevalence of transfusion transmitted infection in Indian scenario. Sci World J.2014. https://doi.org/10.1155/2014/173939.
17. Paul R, Kar S, Zaman FA, Pal S. The quest for an Indian blood law as of blood transfusion services regulatory framework. Asian J Tranfus Sci. 2011; 5(2): 171-4.

18. Mandal R, Mondal K.Transfusion transmissible infections among blood donors from a sub-Himalayan rural tertiary care centre in Darjeeling, India. J Tradit Complement Med. 2016; 6(3): 224-9.

\section{Correspondence to/Autor za korespondenciju}

Musharaf Bashir

Department of Physiology, GMC\&SMHS hospital, Srinagar, J\&K, India.

Contact no: +917042272380 .

Email: dr.musharaf.mb@gmail.com 